\title{
A DUNÁNTÚL SZOLGÁLATÁBAN Előadások Rúzsás Lajos emlékének
}

\author{
Horváth Gy. (szerk.) (1995) MTA Regionális Kutatảsok Központja- \\ Magyar Történeti Társulat Dél-Dunántúli Csoportja, Pécs, 165 o.
}

Nagyon ritka az a kötet, melynek címe pontosan kifejezi annak tartalmát és egyúttal jelzi a szerző tudományos hitvallását. A Rúzsás Lajos 80. születésnapjára rendezett emlékülés elöadásait közreadó kötet esetében találóbb címet nehezen lehetett volna találni. Az 1982-ben elhunyt történész szinte egész életében a régió valamelyik településével, a térség problémáival foglalkozott. Olyan tudós volt, aki négyéves kisgyermekként került Siklósra, s attól kezdve ez a táj gyakorolt rá nagy hatást. Középiskolás és egyetemista évei alatt nagyon megismerte ezt a vidéket, az ott élő polgárokkal együtt. Valószinúleg ez is hozzájárult ahhoz, hogy a három éves fóvárosi tanárkodás időszakában született doktori disszertációján kívül alig van olyan dolgozata, amely más tájról szólna, mint a Dunántúlról.

A tájhoz szorosan kötödỏ tudóst mutatták be az emlékülés elóadói. Az elhangzott elöadásokból a MTA Regionális Kutatások Központja és a Magyar Történelmi Társulat Dél-Dunántúli Csoportja példamutató gyorsasággal tanulmánykötetet adott ki. A Horváth Gyula szerkesztésében napvilágot látott kötet igényes formai kivitelben, stílszerủ borítóval jelent meg. A különböző témájú dolgozatok közös vonása, hogy a szerzők Rúzsás Lajos tevékenységét elemezték, illetve az általa felvetett tudományos kérdések továbbgondolását végezték el.

A térséghez kötődő kollégát mutatja be a kötetben T. Mérey Klára, aki hosszú éveken át közvetlen munkatársa volt Rúzsás Lajosnak. Az életút ismertetése mellett egyúttal egy olyan tudományos múhely szerveződését is nyomon követheti az olvasó, melynek keretei között a történész tevékenykedett. T. Mérey Klára bemutatja Rúzsás Lajos törekvéseit a gazdaságtörténeti szemlélet elterjesztésében és módszereinek kidolgozásában. Az országosan is mintául szolgáló első üzemtörténeti feldolgozások közé tartozott a Zsolnay gyárról készült munkája, majd a Pécs gazdasági életéről írott kủlönbỏző várostörténeti dolgozatok. Nyomon követhetjük a 'Szigetvári Emlékkönyv megszerkesztésében végzett óriási szervező munkát és a Magyarország történetéről szóló sorozat hatodik kötetében - a reformkori iparról, mezőgazdaságról - megjelent országos összesítéseket

Jól egészíti ki az életút bemutatását Sziráki Zsuzsanna összeállítása, amely pontosan közli a hat könyv, az 54 tanulmány, a több tucat recenzió, hozzászólás népszerúsítő cikk és bírálat címét és megjelenési adatait.

A történész szakkörökben nagy érdeklödést kiváltó 1963-as elöterjesztéssel indította meg Rúzsás Lajos - Szúcs Jenő társaságában - a várostörténeti kutatásokat Magyarországon. Az Akadémia által is támogatott feltárások és összegzések kezdetét és a későbbi eredményeket vette számba Benda Gyula. Kimutatta, hogy Rúzsás a program megfogalmazásán túl tanulmányok sorát adta közre a dunántúli 
városokról, kisérletet téve arra, hogy magyarázatot találjon a fejlỏdés térségben tapasztalható megtorpanására. Ezekben a munkákban városfunkciók koronkénti változását mutatta be. A késöbbiekben hasonló alapelvekre támaszkodva több dunántúli településröl készült nagyszerủ feldolgozás.

A térségben megindult várostörténeti feltárások segítették az újabb összegzések elkészítését. Bácskai Vera a 18. századi dunántúli városhálózat bemutatásakor olyan szempontokat is figyelembe vett, melyekre korábban nem fordítottak figyelmet. A térségre a „kisvárosok világa” jellemzö, melyek között néhány település esetében a középkori városi élet folytonossága követhető nyomon, de az újranépesülö oppidumok többsége ismételten kénytelen megszerezni kiváltságait. A 18. századot vizsgáló kutató hasonló számú városi jogállású településsel találkozott a korszak elején, mint a végén, de valójában mindössze harminc töltött be közülük kisebb-nagyobb sugarú körben ható központi szerepkört. A tanulmány jól érzékelteti azt a változást, amely a század folyamán lezajlott, s a régi-új piacközpontok kialakulásához vezetett.

A városhálózat áttekintése után a déldunántúli városok önkormányzatáról irt Kajtár István. A hazai városi igazgatási gyakorlatot egy nemzetközi összehasonlítással együtt vizsgálva a tanulmány kimutatja, hogy a magyar városi jog nem hasonlítható sem a francia-belga-angol, sem a porosz-osztrák modellhez. A sajátosan magyar önkormányzat fejlettsége lemérhető a személyzet számán, annak összetételén, az aktatermelésen, a képviselök foglalkozási megoszlásán, a városok tulajdonában lévő vagyonon. Mindezeket számba véve Kajtár István kidolgozott egy komplex urbanisztikai mutatót, s ennek segítségével villant fel egy képet a térség öt városi jogállású településéröl. A hatalmas mennyiségü adatból jól szerkesztett táblázatokkal és kiváló összefoglalóval ad áttekintést a városokról, melyek müködését - például hivatalnokok létszáma, a gazdálkodás áttekinthetősége terén - figyelmébe ajánlhatjuk a mai polgármestereknek.

A városok fejlödése szoros kapcsolatban állt a kereskedelmi élettel, melyröl somogyi összegzést készített Szili Ferenc. A korábbi és saját kutatásait ötvöző írásból kirajzolódnak a 18 . századi somogyi kereskedelmi élet sajátosságai. A nagyvárosoktól távol esö, az országos utakkal alig rendelkező megyében a Diáva folyó segítette a kereskedelmet, illetve rövid postautak épültek a forgalom lebonyolítására. A tanulmányban sok szó esik a csárdákról, melyek a szórakozás és a szállás mellett az üzletkötések és kifosztások helyszínei is voltak. A szerző megállapítja, hogy a térség modernizációjához szükséges tőke egy része a kereskedelmi tevékenységból eredt.

Rúzsás Lajos könyv formájảban is napvilágot látott kutatásait bövítette tovább Ódor Imre, amikor a Baranya megyei kurialista nemesek sorsát írta meg tanulmányában. Szabadszentkirály több évtizedig tartó, de sikeresen befejeződött harcának bemutatása során többször utal a szerző Rúzsás hasonló kutatásaira, melyekböl kiderült, hogy a szomszédos Bicsérd lakói nem tudták bizonyítani kiváltságos mivoltukat, $\mathrm{s}$ a többi jobbágyfalu sorába kerültek.

A térség mezögazdasági birtokaival többször foglalkozott Rúzsás, s hasonló feltárást végzett el Simonffy Emil is dolgozatában. A nagykapornaki apátsági uradalom úrbérrendezését bemutató tanulmányban aprólékos vizsgálatot végzett a szerző 
a Zalaegerszeg körzetében müködő nagyüzemben. Az egyházi kézben lévó uradalom nagy teruleteket birtokolt Zala megye középső vidékén, ezért fontos volt az ott lezajlott változás. A jobbágyfelszabadítás utáni rendezés 1857-ben indult, $s$ másfél évtized múltával zárult le. A végleges egyezség megkötése után váltak magántulajdonná a volt jobbágytelkek, illetve a jezsuita rend megkezdhette birtokának tőkés gazdasággá történỏ átalakítását.

A Dunántúllal foglalkozó történésznek nincs mindig lehetösége arra, hogy a térséget elhelyezze a nemzetközi eröviszonyok között. Hajdú Zoltán arra vállalkozott, hogy bemutatja a Dél-Dunántúl politikai földrajzi helyzetének történeti változásait. A magyar államiságtól napjainkig húzódó nagyívü összegzésben kitér a legfontosabb korszakok rövid áttekintésére. Joggal állapítja meg a szerzö, hogy a térséget a történelem folyamán a stabilitás és a labilitás egyaránt jellemezte. A Jugoszlávia szétesése utáni helyzetet elemezve a térség instabilitására hivja fel a figyelmet. Ezzel ellentétesen értékeli Ausztria Európa Unióba történő belépését, amely remélhetőleg hosszabb távon elönyöket hoz a térség számára, ellensúlyozva a dezintegrációs folyamatokat.

A kötet Benda Kálmán hagyatékából 11 levelet közöl. Az elsö levelek a pályakezdó Rúzsás Lajos terveivel, háború utáni tevékenységével foglalkoznak. A legtöbb közölt levél az élete fö munkásságának tekintett szigetvari konferencia és emlékkőtet munkálataival kapcsolatos, illetve néhány személyes jellegú méltatás is helyet kapott a dokumentumok között. $\mathrm{Az}$ egyéniséget villantja fel az a két kézzel irt levél, amely másolatban bekerült a könyvbe.

Az emlékülést szervezö intézmény vezetöjeként Horváth Gyula készitett összefog- lalót a Dunántúli Tudományos Intézet 50 éves müködéséröl. Az ország egyetlen nem budapesti székhelyü, társadalomtudományokkal foglalkozó tudományos központja 1943-ban alakult, s nemcsak Dunántúl javára, hanem jórészt a Dunántúl erejéből, ahogyan Rúzsás Lajos 1964-ben leirt mondatát a szerzó idézte. A tájkutatás különböző tudományterületeit összefogó kutatóhely fokozatosan vált országosan, majd világszerte ismertté. A tanulmányból jól kirajzolódik az intézet életében lejátszódott szakmai korszakváltás időszaka, melynek eredményeként ma Magyarországon Pécsett foglalkoznak kutatási programként az európai integrációhoz kapcsolódás elöfeltételeivel. A feltáró s összegző tevékenységet sikerült a hazai felsőoktatásban is különbözö mértékben hasznositani.

A Magyar Történelmi Társulat több mint száz éve a hazai történeti kutatások szervezője és összefogója, illetve a tudományos eredmények népszerüsítője. $\mathrm{Az}$ országos társadalmi egyesület 1949 után állami támogatású - és ellenörzésủ - szakmai szervezetté vált, melynek területi csoportjai alakultak. A dél-dunántúli csoport negyven éves tevékenységét mutatta be Vonyó József. A csoport megszervezésében és müködésében Rúzsás Lajos alapitó tagként müködött közre, s haláláig aktívan dolgozott benne. A negyven év alatt megrendezett elöadói ülések, könyvviták közül a legnagyobb érdeklődést kiváltókat sorolja fel a dolgozat. A baranyai, somogyi, tolnai és zalai levéltárosok, a különbözö iskolákban dolgozó tanárok, a térség kutatói kezdetben helyi, majd országos jelentőségủ konferenciákat szerveztek. A dolgozat részletezi, hogy a Dunántúl településtörténete címet viselö konferenciákon, illetve más hasonló rendezvényeken Rúzsás Lajos milyen meghatározó 
szerepet játszott. Az összegzés további részében az utolsó tíz év változásairól számolt be a szelzö.

A magyar regionális kutatások közül kiemelkedik a dunántúli terület vizsgálata. Az eredetileg néhány fös kutatócsoportból Európában számon tartott Intézet jött létre. Az átalakulás folyamatában nagy szerepet játszott Rúzsás Lajos, aki előtt méltán tisztelegtek kollégái és barátai. A régiót kutató, de a provincialitás veszélyét mindig elkerülő történész munkássága példamutató. A szakma szeretete, a tudományos pontosság, az eredmények továbbadása és az új generációk kinevelése tartozik a rúzsási életúthoz, melyet remélhetöleg méltón folytatnak az utódok.

\section{AZ ÖNKORMÁNYZATOK VAGYONOSODÁSI FOLYAMATA}

Pitti Z.-Varga S. (1995) Közgazdasági és Jogi Könyvkiadó, Budapest, 169 o.

Az elmúlt években az önkormányzati gazdálkodás és a szakmai érdeklödés középpontjába a helyi költségvetés problémái kerültek. A vagyongazdálkodást érintő kérdések közül napirenden volt természetesen a tulajdonmegosztảs mint a helyi önállóság feltételrendszere. A szerzők szándéka szerint kézikönyvként megjelenö kötet a téma fontossága, aktualitása és gyakorlati hasznosithatósága miatt is nagy érdeklödésire számíthat.

$\mathrm{Az}$ elméleti igénnyel feldolgozott témakörök a történelmi fejlödést elemzó és a mai gyakorlatot leíró részeknél, söt a lehetséges jövöbeli (változásokat) alternatívákat felvázoló fejezetekben is, széles körï információk elemzésének tapasztalatain nyugszanak. Külön dicséretes a szerzöknek az a törekvése, mellyel az elemzés alapjául szolgáló adatbázist az olvasó számára is hozzáférhetövé teszik a 26 mellékletben, a 115 . oldaltól a 169 . oldalig tartó terjedelemben. Mindezek mellett az egyes fejezetek mondanivalójának alátámasztására is sok adatot, táblázatot találunk.

Feltétlenül egyet kell értenünk a szerzökkel abban, hogy az önkormányzati szféra vagyongazdálkodása a nemzetgazdaság és az államháztartás szempontjából is fontos kérdés, hiszen már ma is az önkormányzatok tulajdonát képezi a nemzeti vagyon kb. egynegyede. (3-4000 Mrd Ft), mely az állam vállalkozói vagyonának mintegy kétszerese. A stratégiai gondolkodók azzal számolnak, hogy a következő évek tulajdoni mozgásai már a helyi társadalom érdekszférájában, az önkormányzatok körében fognak létrejönni ( I I. o.).

A nagyon rövid, de a téma szempontjából fontos mondanivalót tartalmazó történeti rész az 1870-1990 közötti időszak pénzügyi szabályozásait elemzi. Megállapítja, „...hogy az autonómiára vonatkozó elvek soha nem érvényesültek maradékta- 